\title{
Teaching NeuroImages: The Trigeminal Pontine Sign
}

\section{Centripetal Migration of Herpes Virus to the Central Nervous System}

Fajun Wang, MD, and Hesham Abboud, MD, PhD

Neurology ${ }^{\circledR}$ 2021;96:e1387-e1388. doi:10.1212/WNL.0000000000010845

Figure Brain MRI Findings

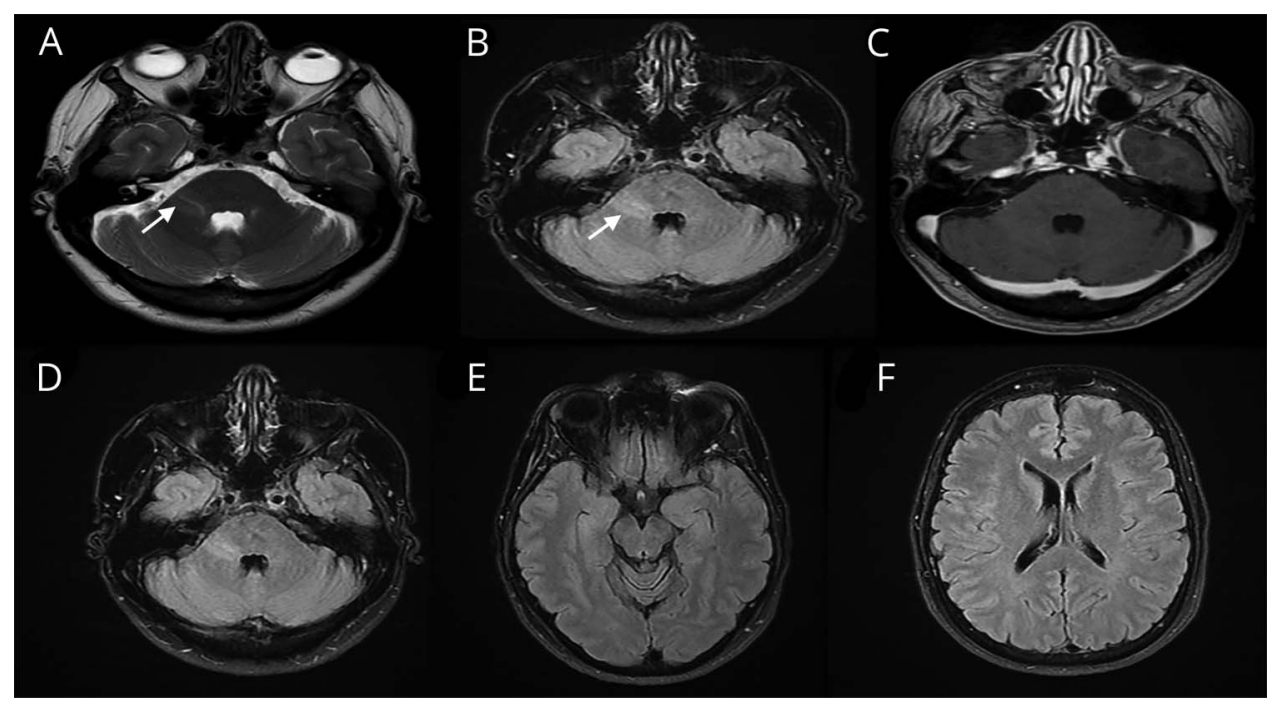

(A and B) T2-weighted and fluid-attenuated inversion recovery (FLAIR) axial images depict hyperintense band signal within the right trigeminal root entry zone (white arrow) representing sequela of limited (nondisseminated) centripetal herpetic migration from the gasserian ganglion to the trigeminal fibers. (C) T1-weighted axial postcontrast image showed no enhancement suggesting chronic sequela rather than active infection, hence the negative CSF viral studies. (D-F) FLAIR axial images 4 months later showing persistent trigeminal pontine sign and no new demyelinating lesions.

A 53-year-old woman with recurrent right lower lip cold sores presented with a 2-year history of hyperesthesia in the right V3 distribution. Brain MRI showed a nonenhancing band-like T2 hyperintensity from the trigeminal root entry zone to the dorsolateral pons (figure). Spinal fluid was negative for oligoclonal bands, HSV1/2 PCR, and varicella PCR/IgG. Repeat MRI after 4 months showed no new lesions. The trigeminal pontine sign reflects possible limited centripetal migration of herpes virus from the Gasserian ganglion to the intrapontine trigeminal fibers and sensory nucleus causing demyelination and cell death. ${ }^{1,2}$ It must be differentiated from other causes of demyelination like MS.

\section{Study Funding}

No targeted funding reported.

\section{Disclosure}

Dr. Wang reports no disclosures. Dr. Abboud is a consultant for Biogen, Genentech, Sanofi Genzyme, Celgene, Alexion, and Viela Bio. Go to Neurology.org/N for full disclosures.
Correspondence Dr. Abboud hesham.abboud@ uhhospitals.org

\section{MORE ONLINE}

$\rightarrow$ Teaching Slides

links.lww.com/WNL/ B218

From the Multiple Sclerosis and Neuroimmunology Program, University Hospitals Cleveland Medical Center; and Case Western Reserve University, Cleveland, OH. 


\begin{tabular}{lll}
\hline Appendix & Authors & \\
\hline Name & Location & Contribution \\
\hline $\begin{array}{l}\text { Fajun } \\
\text { Wang, MD }\end{array}$ & $\begin{array}{l}\text { University Hospitals of } \\
\text { Cleveland/Case Western } \\
\text { Reserve University, } \\
\text { Cleveland }\end{array}$ & $\begin{array}{l}\text { Study concept and design, } \\
\text { first draft, and literature } \\
\text { review }\end{array}$ \\
\hline $\begin{array}{l}\text { Hesham } \\
\text { Mbboud, }\end{array}$ & $\begin{array}{l}\text { University Hospitals of } \\
\text { Cleveland/Case Western }\end{array}$ & $\begin{array}{l}\text { Study concept and design, } \\
\text { data acquisition, literature } \\
\text { review, and revised the } \\
\text { Reserve University, } \\
\text { Cleveland }\end{array}$ \\
& & $\begin{array}{l}\text { manuscript for intellectual } \\
\text { content }\end{array}$ \\
\hline
\end{tabular}

\section{References}

1. D'Amico A, Russo C, Ugga L, et al. Can pontine trigeminal T2-hyperintensity suggest herpetic etiology of trigeminal neuralgia? Quant Imaging Med Surg 2016;6:490-495.

2. Haanpää M, Dastidar $P$, Weinberg A, et al. CSF and MRI findings in patients with acute herpes zoster. Neurology 1998;51:1405-1411. 


\section{Neurology}

\section{Teaching NeuroImages: The Trigeminal Pontine Sign: Centripetal Migration of Herpes Virus to the Central Nervous System}

Fajun Wang and Hesham Abboud

Neurology 2021;96;e1387-e1388 Published Online before print September 14, 2020

DOI 10.1212/WNL.0000000000010845

This information is current as of September 14, 2020

Updated Information \& Services

References

Subspecialty Collections

Permissions \& Licensing

Reprints including high resolution figures, can be found at: http://n.neurology.org/content/96/9/e1387.full

This article cites 2 articles, 1 of which you can access for free at: http://n.neurology.org/content/96/9/e1387.full\#ref-list-1

This article, along with others on similar topics, appears in the following collection(s):

All Demyelinating disease (CNS)

http://n.neurology.org/cgi/collection/all_demyelinating_disease_cns Viral infections

http://n.neurology.org/cgi/collection/viral_infections

Information about reproducing this article in parts (figures,tables) or in its entirety can be found online at:

http://www.neurology.org/about/about_the_journal\#permissions

Information about ordering reprints can be found online:

http://n.neurology.org/subscribers/advertise

Neurology ${ }^{\circledR}$ is the official journal of the American Academy of Neurology. Published continuously since 1951, it is now a weekly with 48 issues per year. Copyright (C 2020 American Academy of Neurology. All rights reserved. Print ISSN: 0028-3878. Online ISSN: 1526-632X.

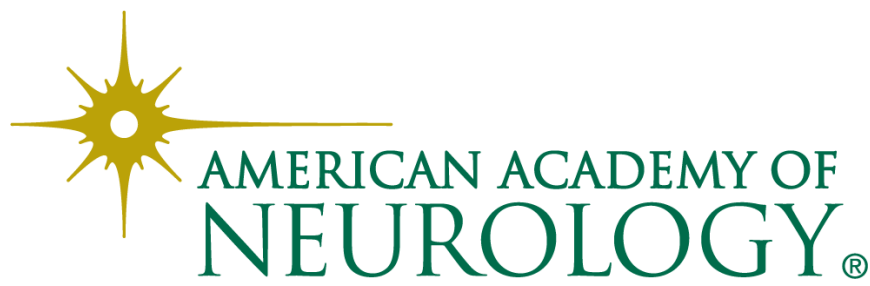

